\title{
OCCASIONALISMS IN ADVERTIZING COPIES (AS EXEMPLIFIED BY SLOVAK, BULGARIAN AND UKRAINIAN LANGUAGES)
}

\author{
Lidija KHODA \\ Ivan Franko National University of Lviv \\ E-mail: lidiacherniukh@ukr.net
}

\begin{abstract}
In the article, occasionalisms as individual authored new formations in Slovak, Bulgarian and Ukrainian advertising texts were researched. The state of studying the selected scientific problems was analysed, as well as different views of scientists on the interpretation of the concept of 'occasionalism' and the use of various terms for its designation (occasional derivation, advertising new formations, potential words, etc.) were considered. Attention was drawn to the distinction between the terms of 'neologism' and 'occcasionalism'. In the article, the reasons for lexical innovations appearance in advertising language were also studied, its functions were considered. According to the grammatical affiliation of occasionalisms in the advertising language, occasional verbs, nouns, adverbs, and adjectives were analysed, the peculiarities of its formation and use in advertising texts were found out, as well as a comparative analysis of some lexical units functioning in the texts of Slovak, Bulgarian and Ukrainian advertising was performed. A particular attention was given to occasional phrases, which acquire new shades in advertising due to an unexpected combination of words. According to word formation classification of occasionalisms, such ways of its creation were considered as prefix, suffix, prefix-suffix, word compounding, word stem compounding, and graphic derivation. Graphic occasionalisms occupy a significant place in the advertising texts, which arise from the type of highlighting certain letters, replacing individual letters with different symbols or borrowed letters, etc. Based on the material analysed, the influence of occasionalisms on the consumer during the perception of advertising texts was determined.
\end{abstract}

KEYWORDS: occasionalisms, individual authored lexical new formations, advertisement, advertising text, advertising language, advertiser

Advertisement as a permanent source of information is changing and being updated day by day; it never stands still. In order to get the consumer interested in some new information and eventually succeed, advertising uses all possible persuasive techniques. Creating efficient advertising texts is a process that requires the copywriter to select certain language means in addition to possessing the sense of speech, creative thinking, ability to play with words, so that to make the recipient's address both informative (delivering the content and ideas) and involving as well as efficient. For this purpose, advertisers enrich the language with occasional, newly-coined words.

The problem of nonce words in the discourse of advertising has been studied by Ukrainian and scientists from different countries such as O. Orgonyova, V. Malikova (2005), P. Obornik (2013), D. Todorova (2008), L. Khavkina (2010), L. Dyadechko (2009), O. Makedonova (2016) among others.

However, taking into consideration a continuous process of information updating, little attention has been paid to Slovak advertising copies, while advertising copies containing nonce words in Bulgarian and Ukrainian require deeper investigation.

Rationale. The accumulation of advertising copies containing occasionalisms is a matter of growing interest to both the recipients and advertisers, which encourages in-depth study of the specific features of occasionalisms in advertising copies.

The purpose of the study is to analyze the functioning of occasionalisms in the texts of Slovak, Bulgarian and Ukrainian advertisements (according to the grammatical and word-formation classification), and to determine their impact on the recipient in the process of perceiving advertising texts.

The source of the factual material for this study were commercial advertising copies which appeared in the Slovak, Bulgarian and Ukrainian media space during 2012-2019. A significant amount of material are the texts of outdoor (street) advertisement (billboards, leaflets and booklets); texts recorded in the periodical editions and on www.youtube.com; as well as texts on Slovak, Bulgarian and Ukrainian television.

In the linguistic science, it is believed that the concept of occasionality was first grounded by the German philologist G. Paul in 1880. The term "occasional" (from the Latin occasionalis random) was first used in 1957 by the researcher N. Feldman. Today, scientists use different terms to refer to these lexical units. In this context, it is worth mentioning the study by A. Turchak (2013) analyzing scientific literature dedicated to the problems of occasionalisms, where she notes that 
researchers allocate more than 30 terms for the designation of these lexical units (for example, occasional word, disposable neologism, author's neologism, coinage, and others).

Apart from various terms used for the designation of these concepts, scientists interpret the term "occasionalism" in somewhat different ways, noting that the term is not clearly defined.

In order to clarify the essence of the "occasionalism" concept, for J. Kolois, "it is necessary to seek new, non-traditional approaches, since the traditional ones are not suitable anymore for the research of the entire variety of occasional phenomena, which, as a result of derivational processes, are represented as newly created lexemes, sememes, grammemes, phrasemes and syntax nomemes" (Kolois, 2007, p. 10). In view of this, the researcher points out the term "occasional derivation", which is "a process of materialization, actualization of language potentials, the process of formation of new nominative units (in particular lexical ones but not limited to them) on the basis of the used material adapted in the" linguistic space" (ibid.).

In terms of advertising, according to L. Khavkina, the term "occasionalism" is not considered as universally applicable in the analysis of advertising discourse, since such words are formed not by chance, but for a certain purpose; in addition, they may be used out of context and even come into vernacular usage" (Khavkina, 2010, p. 274). The researcher highlights advertising innovations, which include neologisms, and considers occasionalisms as a kind of neologisms - neologisms as such (ibid.).

It should be noted that scientists' opinions regarding the delineation of the terms "neologism" and "occasionalism" are ambiguous. Neologisms are regarded as new lexical units, which denote a new, previously unknown, non-existent concept, subject, branch of science, occupation, etc. (Malarchuk, 2015, p. 138). Note that the subject of research by many scientists is precisely the criteria for the differentiation of occasionalisms among other new lexical units. For instance, L. Dyadechko (2009) suggests the following criteria for differentiating: lexicographic (occasionalisms belong to speech, not the language, they are not recorded in dictionaries and used irregularly), word-formation (the emergence of occasionalisms is often accompanied by language deviation), expressive-stylistic (occasionalisms have a high degree of expressiveness adding to emotionality of the text).

In linguistics, experts exploring occasionalisms single out another term for the designation of new lexical units - "potential words". For example, L. Kravchuk names the main features which are different in occasionalisms and potential words (regular, usual formations whose structure is found in existing lexical units), noting that "the interpretation of occasionalism as an unusual, mostly expressively coloured word formed on the basis of an available word or phrase, sometimes in breaching the laws of word formation or the linguistic norm, which exists only in the context it arose in is linguistically grounded" (Kravchuk, 2016, p. 6).

The most distinguishable functions of occasionalisms include evaluating, emotional, nominative and advertising function of occasional. Some researchers, for example, E. Romanchuk (2011), call the characterizing function as the main one. Defining a new object or phenomenon in advertising, occasionalisms perform a nominative function, but unlike with neologisms, it is not the main one. First of all, occasionalisms in advertising trigger a certain emotional reaction from the consumer by means of enhancing the expressiveness of the whole statement with the original disclosure of additional features of the product advertised. Therefore, in my opinion, the advertising function of occasionalisms is in combination of the emotional, positive evaluating, and nominative functions, which collectively make up the function of characterizing.

I believe that in the discourse of advertising, it is important to distinguish between the notion of "neologism" and "occasionalism". Thus, we will put an increased focus on some of the advertising neologisms which are quite often considered as occasional.

A good illustration are neologisms fixed in advertising copies which are created using the borrowed prefixes super-, mega-, ultra-, extra-, etc., prove the influence of foreign language culture and emphasize that the advertised product is on the cutting edge, however, no longer will they surprise the consumer with a novelty in terms of form or content. We can assume that this is also due to the appearance of a large number of similar promotional texts. For example:

Lidl. Super víkednd; Möbelix. Mega výpredaj konči; (Slovenské letáky, 2018); SolarStrap. Ultral'ahká solárina nabijačka pre všetky typy mobilov a mp3 prehrávačov (Slovenské letáky, 2012); Datacomp. Extra porcia pamäte zadarmo (Slovenské letáky, 2018);

Savex. Супер лесно, супер ароматно (youtube, 2018); Техномаркет. До -30\% сега над 
2000 мега предложения outlet; Tesi. Ултра тънка тоалетна седалка; Metro. Extra оферти; Согеgа. Екстра силен. Оригинален вкус (Bulgarian brochures, 2019);

Savex. Cупер порошок за суперціною (Ukrainian promotional cards, 2018); Фокстрот. Мега Розпродаж Bref. Ультра ефективний у всій оселі (Ukrainian promotional cards, 2017); Color Expert. Екстра стійкий колір (Ukrainian promotional cards, 2019).

It should also be noted that in the analyzed advertising texts these prefixes are spelled in different ways: both together and separately; in languages that use the Cyrillic, Latin is sometimes used.

It is apparent that advertising copies with neologisms are easy to remember, but in my opinion, they have fewer competitive advantages compared to the texts that contain occasionalisms, which make the advertisement unique and recognizable. That becomes evident while exploring advertising occasionalisms in the research.

Researchers such as T. Zabolotna and N. Khristich consider "advertising coinage as the author's individual creative work, since during the creation of an advertising text, the idea can be put in various ways, using a lot of lexical-stylistic shades of meaning" (Zabolotna, Khristich, 2014, p. 192 - 194). In view of this, scholars consider the highlighting of initial letters or individual words in large print, onomatopoeia, puns, acronyms, etc., as such newly-coined lexical means. It should be mentioned that researchers often consider this phenomenon within the limits of graphical, phonetical and other methods of word-play in advertising. I consider such a range of research appropriate, since the origin of the word-play in advertising is the creative approach to the creation of the text.

This study will consider occasionalisms in advertising as individual, created by a particular copywriter (although hidden, unknown to the public) new lexical units (original and expressive) that operate in specific texts of a particular advertisement which is one of the most popular kinds of the word-play. It should also be stated that occasionalisms may also be borrowed from other languages. Advertising occasionalisms are always characterized by a sense of novelty, something unusual, abnormal, and distinctive.

According to the grammatical nature of occasionalisms, as the analysis shows, Slovak, Bulgarian and Ukrainian copies are saturated with occasional verbs, nouns, adverbs and adjectives. To illustrate, it is common to come across occasional verbs which are derived from the name of the product:

Zwack. Zwackni si pravý citrus; Kofolonizuj svet. Kofola (Slovenské letáky, 2012); Twistujte s nami! AXE TWIST (Slovenské letáky, 2013); Laysni si viac! Zemiakové lupienky Lays (Slovenské letáky, 2014);

Фанта. Фантазирайте (Bulgarian brochures, 2013);

SНАКанемо, бебі. Shake (Ukrainian promotional cards, 2012); Фанта. ФАНТАнусмо пригоди (Ukrainian television, 2014).

It is obvious that all the appeals to the consumers are easy to remember and catchy, dynamic as they are used in the Imperative Mood for the $2^{\text {nd }}$ person singular or plural and the $1^{\text {st }}$ person singular and encourage the consumer to act. However, in the course of the study, I discovered that such occasional lexemes in Bulgarian and Ukrainian advertisement have a narrower range of functioning compared to Slovak advertising texts.

It should be noted that not all occasional verbs are derived from the proper name of the goods, there are those that affect the content of the text due to associations they have to the subject of advertising:

Sušienky Oreon. ... omliekuješ a potom zješ (Slovenská televízia, 2015);

Фрапирай лятото. Nescafé frappé (Bulgarian brochures, 2012); Leki. Вкусмихни се! (youtube, 2018); Супичка. Зима е! Засупи глада!; Avon scentini. “Коктейлизирайте”” стила си!; Сльнчакам те! Покана за среща на Сльнчев бряг. Lidl (Bulgarian brochures, 2019);

Йогурти від Danone. Йогуртуй фантастично (уoutube, 2018); Lion Just Wild Apaxic. Охрумтіти можна (Ukrainian television, 2018); Пивний чемпіонат 9 червня. Футболіємо разом! (Ukrainian promotional cards, 2016); Майстеркласимо? Забігай в Будинок іграшок святкувати та в ігри грати (Ukrainian promotional cards, 2019).

The language of advertising texts sometimes contain occasional verbs which distort already known literary words (with the replacement of one or more letters), or individual words are presented in their abbreviated form, usually to emphasize the name of the advertised product: 
Fiber (instead of vyber) si na Vianoce niečo extra. FiberNet. FiberTV. FiberTel v našej najlepšej ponuke roka. Orange (Slovenské letáky, 2012);

Чіпси Люкс. Живи, як ти лю (instead of любии)! (Ukrainian television, 2018).

Occasional nouns owing to their novelty, intensity and accuracy nominate certain phenomena, objects, notions, etc.:

HRAtislava (instead of Bratislava) je vikend plný hier - príd'te ho zažit' (Slovenské letáky, 2013); Fajn Life. Značková kvalita za Fajn cenu (Slovenské letáky, 2018); Kebab. Cool ponuka končí Vianočná reklama podl'a Funfónistov. FunFón (Slovenské letáky, 2019);

Вземи ВІО решение за деня!; Кибер петък. 23-24 ноември 2017; Jacobs Monarch. Уникален чаромат (Bulgarian brochures, 2018);

Кетчуп Чумак. Настав кінеиь сірим блюдням (youtube, 2015); Actimel. Актимелятко завжди приносить користь (Ukrainian television, 2015); Епікур. Свіжий кур (instead of свіжа курятина) (Ukrainian television, 2018); Watsons. Щедрих даросвят! (Ukrainian promotional cards, 2016); Актуаль. Зустрічайте АКТУАЛЬних свіжсамінів (instead of вітамінів); Prostor. Щастинка щастя (instead of частинка); Мобілич для своӥх. Стартовий пакет Київстар; Хомка. Мах обсмаження (Ukrainian promotional cards, 2018); Відчуй вдосконалене багатство аромоксамиту. Jacobs obarch (youtube, 2018); Знову в Там Там. Казкова чудоляндія. Шалене свято для усіх дітей! (Ukrainian promotional cards, 2019).

Occasional nouns formed by means of the borrowed component -mania are also popular colouring the advert with passion and drive:

Vikendománia len do nedele. Mall.sk (Slovenské letáky, 2017);

Голяма сезонна шопинг мания! Avon (Bulgarian brochures, 2015); Nerf. Nerf мания. Само в Хиполенд (Bulgarian brochures, 2016);

Тільки на watsons.иа. Шопінг Манія (Ukrainian promotional cards, 2018).

Interestingly, the occasional noun in Slovak advertising of the Kofola drink, is where Fofola is different from the name of the advertised Kofola product with just one letter. On the basis of that, copywriters derived new words in the slogans of this advertisement (represented not only by nouns but also verbs), such as fandále (instead of sandále), pfipravil fom (instead of pripravil som) that emerged as a depiction of the dog's (that is the main character of the ads) articulation disorder: 2015).

Dáš si Fofolu? Kofola (youtube, 2015); Pfipravil fom ti fandále. Kofola (Slovenská televízia,

In my opinion, such humorous word distortion draws even more attention to advertised items.

Occasional adverbs are derived from the proper name of the goods as well as those associated with the product:

Bonus Book. Ži bonusovo! (Slovenské letáky, 2012); Aegon. Myslite aegonomicky (Slovenské letáky, 2013);

Fa. Чувствай се $\boldsymbol{F a н т а с т и ч н о ~ ( y o u t u b e , ~ 2 0 1 5 ) ; ~}$

Золота Амфора. Живи амфорично (Ukrainian promotional cards, 2014); Lipton. Живи почайному; Тук. Хрустато тане!; Геркулес. Язичкам чутніше! Язичкам нюхніше! Язичкам видніше! (Ukrainian television, 2018); Епіцентр. Феєрично-сантехнічно; Нова Активіа. Подбай про себе суперзлаково! (Ukrainian television, 2019).

It should be pointed out that in Bulgarian and Ukrainian advertising texts, occasionalisms often arise as a result of the merging of the Latin (the name of a foreign product, for example, $\boldsymbol{F} a$ ) and the Cyrillic (Fantastic).

The quality of the advertised product is clearly emphasized by occasional adjectives that are bright and emotionally coloured:

Funko. Funtastická (instead of fantastická) hudba (Slovenské letáky, 2013); Všetky kabelky sú kabelkové, ale naše sú Najkrajšie. www.najkrrajsiekabelky.sk (Moja psychológia, s. 123); Halloweenská cenová párty. Elektro (Slovenské letáky, 2017);

Fanta. Fantacmичен летен вкус (Bulgarian brochures, 2012); Rufflex maxx. Махх хрупкав. Махх вълнички. Махх вкус (youtube, 2016) (NB! Apart from the occasional adjectives, the text contains two occasional nouns: Махх вълнички. Махх вкус);

Jacobs Millicano. Найкав'ярніша кава вдома; Галичина. Чисто-молочний (Ukrainian television, 2018).)

In addition to occasional verbs, nouns, adjectives, and adjectives, it is worthwhile paying 
attention to the use of occasional collocations in the language of advertising under which we consider the words which acquire new shades of meaning different from standard language meanings owing to unexpected combination of words:

Naša XXL ponuka je zaujímavá pre všetkých. Lyreco (Slovenské letáky, 2017); XXL týždne v Lidli; Alza.sk. Masaker cien (masaker - hromadné zabijanie, krviprelievanie) (Slovenské letáky, 2018);

Lidl. Експлозивни предложения XXL; Седмица XXL. Lidl; Разтапящи предложения! Lidl; Ароматизирай лятото. Deо (Bulgarian brochures, 2018); Престъпно вкусен. Кроасан. Lidl (Bulgarian brochures, 2019);

Cоса-соla. Лимон вражсень (instead of мільйон вражень); Cytrus.иа. Ціни плавляться!; Metro. Ламасмо ціни; Зустрічай сезон чорничних дощів. Somersby (Ukrainian promotional cards, 2018); Пумб. Не консервуйте свої гроші (Ukrainian promotional cards, 2019).

It is common for Ukrainian texts to replace one word or collocation with the name of the product or other words:

Norven. 3 Norven роком! (instead of 3 Новим роком!); Цінг-Конг (instead of Кінг-Конг) прийшов - ціни тріщать! Сільпо (Ukrainian promotional cards, 2018).

Another classification of occasionalisms different from the grammatical one is wordformation within which it is common to single out prefixation, suffixation, stem composition, telescopy, and graphic derivation:

Mestský vkus - ukáž tvoj ženský štýl za wow-ceny. Väčši výber oblečenia na bonprix.sk; Vymeňte staré pôzzičky za šetripôžičku a ziskajte spät' $10 \%$ z každej splátky. VÚB BANKA (Slovenské letáky, 2017);

Кока-кола. Жаждогасител (Bulgarian brochures, 2012); Хипо топ намаление на избрани играчки. Хипо Land (Bulgarian brochures, 2019);

Нова Лінія. Новорічний низькоцін (Ukrainian promotional cards, 2014); Сир Хрум. Вгамуй монстроголод, вигравай призи; Жовто-сирний логотип, сир Пирятин - фаворит (Ukrainian television, 2018); Дивопечиво Орео; Плането Кіно. Твоє кінощось!; Грош. Завантажуй мобільний додаток "Грошоманія" та здійсни реєстрацію безкоштовно; Наша Ряба. Безкомпромісний мама-контроль; Мама-контроль якості (Ukrainian promotional cards, 2018).

Derivation by means of prefixes adds a lot to creating new words in advertising:

Avenue. Najnákupy (instead of najlepšie nákupy) a zábava v Humennom; Báječná žena. Maxičislo, ktoré si zamilujete (Slovenské letáky, 2018);

Рекламни услуги. Мулти дизайн ЕООД; Lila. Дизайнерска макси мода създадена в България! (Bulgarian brochures, 2019);

Миргородська лагідна. Анти Zотbі ефект; Аквапарк юрського періоду "Dream Island". Аква-веселий Новий Рік (Ukrainian promotional cards, 2018).

Suffixation is another productive method of coining advertising occasionalisms:

Terno LETÁKovka (Slovenské letáky, 2017); Exquisit. Exquisitná kvalita na sviytočnú náladu; Ziskaj BBDR boxík (Slovenské letáky, 2019);

Lidl. Щастливо бебство (Bulgarian brochures, 2019);

Радіо Люкс. Люксова команда; Фокстрот. Копійчужка - унікальна ціна, щуо не літає; Морозиво ТМ “Рудь". Обмін рудиків (Ukrainian television, 2019).

Prefixation and suffixation are obviously more productive in nouns and adjectives, and less often in verbs.

In Ukrainian advertising texts, word-formation with both prefixation and suffixation is used for coining nonce words:

Чумак. Найпомідорніша томатна паста; Найкавовіша кава. WOG (Ukrainian promotional cards, 2018).

Graphic occasionalisms are getting more and more popular, and their impact is hard to underestimate. For example, certain letters within a word are capitalized, which make up the product name or the action related to the advertised object. In such a way, one word (sometimes altered, e.g МАМАленька) conveys two meanings thanks to graphics (e.g. мама and маленька).

Ziskaj prEVAhu nad mestom. Novwithin ý Peugeot 107 eva v limitovanej edicii len za $8490 €$ (Eva, 2012 p., s. 11); BYVANO. Áno pre vaše bývanie (Living reality, s. 13); Bud' moje BaBy. BB Cream (Eva, s. 17); Naj Elektrodom. Decem BER 5000 smartfónov zadarmo; Výpre DAJ az do 50\% 
menej za techniku. Naj Elektrodom; Planeo Elektro. Vieme, že máte radi zlavy a preto vypreDÁVAME (Slovenské letáky, 2016); Home elektro. októBER, zl’avy BER! (Slovenské letáky, 2019);

Lidl. Понякога се отчАЙвам... Просто си се обезводнила... Животът е розов (Bulgarian brochures, 2017); Kaufland. КОРЕнно различна КОМбинация; Рекламна агенция Рrо Solution. OтПЕЧАТай Твоите идеи с Нас; ДЗП. Да се Забавляваш Постоянно; Lidl. Deluxe Brie. C вино е бри-лянтно; Lidl. A едно време, като бях СТУДЕНm; Lidl. Не се тревожи за килоГРАМИте в неделя; Lidl. Щастието е подНОСА ти! (Bulgarian brochures, 2018);

Effie. Еffiегенна нагорода (Ukrainian promotional cards, 2016); Кодрекс Макс грип. МАКСимум сили в 1 дозі (Ukrainian television, 2017); Bifidus. МАМАленька підзарядка; Комп'ютерний всесвіт. ПОДАРУНКИ ТРИмай (Ukrainian television, 2018); Нова штУКа від голоду. Тис сметана з иибулею (Ukrainian promotional cards, 2018); Бери участь в акиії та вигравай квитки на кониерт “Океану Ельзи” в Києві. Відкрий свОЕ серие. Пиво Львівське (youtube, 2018).

It is obvious that in some texts not only are separate parts of words capitalized but also the words themselves are spelled as two separate words (e.g., Decem BER). One cannot miss such graphic occasionalisms and so they are visually perceived and remembered.

Consumers' attention is also drawn to bright texts with various symbols instead of letters. The most common case is the use of \% symbol instead of certain letters in the word. Such an encoded sense is observed in advertising copies in different languages. Besides, graphic derivation most frequently occurs with the letter $-o$ :

Sme zl'avy, z ktorých \%dpadneš.sk. (\% instead of -o) www.odpadneš.sk (Slovenské letáky, 2013); Quatro. Nakúpte šik0\%vne (\% instead of -o); Potraviny Kačka. Cenové bomby (-o is replaced with a bomb with a \% symbol) (Slovenské letáky, 2019);

Emag. B\%ack (\% instead of -l) friday. Денят с най-много и най-големи намаления (Bulgarian brochures, 2018); e\%a.bg (\% instead -h). Портал за намаления (Bulgarian brochures, 2019);

Ельдорадо. Супер розстр0\%чка (0\% instead of -о) на всі групи товарів (Ukrainian promotional cards, 2013).

It is also popular to replace -o with a picture of a smile:

Experiment Ambi Puru. Dýchajte s radostou (youtube, 2013); Bon Pari (a smiling apple instead of -o) (Slovenské letáky, 2018);

Ново!!! (the picture of eyes instead of both -о letters with a mouth under the letters) Магазин Астрономия за дей (Bulgarian brochures, 2018); Smilebox. Подари усмивка за празника на любовта (Bulgarian brochures, 2019).

Other graphic symbols have also been noticed in advertising. For example:

$W C+$ BIDET. Dva V Jednom (letter -o is replaced with a construction $2 \mathrm{v} 1$ placed in a circle (Slovenské letáky, 2013); Valentínske kefky od Curaprox. Čisté zuby pre krajšie bozky (letter -o is replaced with a heart) (Slovenské letáky, 2019).

Траяна. Кръгче сладост (-о is replaced with a cookie) (youtube, 2015); Кулинарно.bg (-о is replaced with an apple); Всичко за кулинарията (Bulgarian brochures, 2018); Домашен (-о is replaced with a heart) интернет не ми се излиза. Евроком HET; Philicon (-о is replaced with a tomato). Шкумбата лютеница; Billa. Хляб (one part of the letter $-x$ is replaced with a picture of a loaf of bread) на месеи март (Bulgarian brochures, 2019);

ЕКО Маркет. Бабо\$и (symbol \$ instead of $-c$ in a slang word бабоси) для боса; Спробуй гарбузове лате ( -о is replaced with a pumpkin). C Wog cafe (Ukrainian promotional cards, 2018).

There are a few texts in Slovak and Bulgarian advertisements in which occasionalisms are a mixture of figures and letters which make up a single word:

Sloboda 100jí (instead of stoji) za to! S novým paušálom Sloboda 100 voláš a dátuješ v celej EÚ bez viazanosti! (Slovenské letáky, 2018);

OMV. Чи100 u npo100 (Bulgarian brochures, 2018).

As evidenced by this research, some advertising occasionalisms can be considered both at graphic and phonetic level. In advertising, these are occasionalisms that distort literary words (by replacing one or more letters, which are sometimes borrowed) usually to emphasize the name of the advertised product. It should be noted that the phonetic coincidence of single letters in the word might 
not be noticed by the consumer, but at the graphic level, this conscious phonetic deviation is reflected in the advertisement rather vividly:

Park Snow. Dovolenka snow (instead of snov) pre celú rodinu na Donovaloch! (Slovenské letáky, 2012); Hovor všätkým (instead of všetkým) aké máš Ägo (instead of ego) s novou SIMkou FunFón si mädzi (instead of medzi) sebou voláte len za 6 cäntov (instead of centov) za minútu (Slovenské letáky, 2017);

Само кажи БЛАGОДАРЯ. Globul (Bulgarian brochures, 2012);

Купуй Wласне (instead of власне) - мандруй класно! Watsons (Ukrainian promotional cards, 2018); Dynamix Energy. Z-Z-Zарядись! (Ukrainian television, 2018).

A recent advertising text showed an example of onomatopoeia, which is typical of not only Ukrainian texts, but also Slovak and Bulgarian. Such a word play results in the occurrence of interesting occasionalisms, which are represented at two levels - phonetic and graphical:

Mall.sk. Milióóóny prianí, jeden Mall; Volajte dlhooooo s Easy Time; Billa plus. Tááááák vel'ké nákupy! (Slovenské letáky, 2012); Tesco. Jééééééj aké krásne hračky; Naaajväčší black friday práve teraz. Mall.sk (Slovenské letáky, 2018);

Евробанк. Мнооого висока лихва 28\% (Bulgarian brochures, 2013); Всички Ооо!бичат. Leki прОоО!дукти; Пазарувай и печери награди. Меtro. Имаме гоооооол (Bulgarian brochures, 2018);

Ло-ло-локиина Ролтон. Ого яка! (Ukrainian television, 2018); Prostor. Страш-и-и-ні бонуси. Тільки 31.10.2017 (Ukrainian promotional cards, 2017).

It is remarkable that occasionalisms are generally able to transform into oral communication between consumers, however, it is not the introduction of these innovations into a common use that matters to advertisers, but the presentation of advertising information in a way that is original, and therefore effective.

Conclusions. Occasionalisms make advertisements original, creative, expressive, entertaining, unique, and standing out from a variety of similar ones, and at the same time easy to memorize. Occasionalisms indicate the development of the advertising language, the abundance of the linguistic expression of the recipient, and the creative individuality of its creators. It is worth saying that in the analyzed advertising copies, I did not observe occasionalisms with negative connotations, but neutral and positive only. Therefore, the analysis of occasionalisms with negative semantics either in the mass media language, or within the scope of political advertisement survey will be an interesting aspect of the study.

BIBLIOGRAPHY:

Български брошури (2012 - 2019)

Дядечко, Л. (2009)

Заболотна, Т. \& H. Христич (2014)

Колоїз, Ж. (2007)

Кравчук, Л. В. (2016)

Макєдонова, 0. (2016)
Български брошури. 2012; 2013; 2015; 2016; 2017; 2018; 2019. (Bulgarian brochures. 2012; 2013; 2015; 2016; 2017; 2018; 2019.)

Оказіоналізми в сучасних рекламних текстах: когнітивно-прагматичний i соціофункціональний аспекти // Studia linguistica, с. 76 - 83. (Diadechko, L. Occasionalisms in the modern advertising texts: cognitive, pragmatic, social and functional aspects // Studia linguistica, p. 76-83)

Оказіоналізми в англомовній рекламі // Теоретична і дидактична філологія, вип. 18, с. 191 - 194. (Zabolotna, T.\& N. Khristich. Occasionalisms in the English language advertising texts // Teoretychna i dydaktychna filolohija, vyp. 18, s. 191 194.)

Оказіональна деривація: теоретичний та функціонально-прагматичний аспекти. Автореф. дис. доктора філол. наук, спец. 10.02.01 “Українська мова". Київ. (Kolois, Zh. Occasional derivation: theoretical, functional and pragmatic aspects. Avtoref. dys. doktora filol. nauk, spec. 10.02.01 "Ukraiinska mova". Kyiv.)

Семантико-функціональний потенціал оказіоналізмів у текстах засобів масової інформації початку XXI століття. Автореф. дис. ... канд. філол. наук, спец. 10.02.01 "Українська мова". Київ, 22 с. (Kravchuk, L. V. Semantic and functional potential of occasionalisms in mass media texts at the beginning of the XXI century. Avtoref. dys. ... kand. filol. nauk, spec. 10.02.01 "Ukraiinska mova". Kyiv, 22 c.)

Механізми творення оказіоналізмів у сучасних англомовних рекламних текстах // Філологічні науки, кн. 1, с. 63 - 66. (Makiedonova, O. Mechanisms of 
Малярчук, О.В. (2015)

\section{Романчук, С.C. (2011)}

Тодорова, Д. (2008)

Турчак, О. М. (2005)

Українські рекламні листівки (2012 2019)

Українське телебачення (2014 2019)

Хавкіна, Л. (2010)

Eva (2012)

Eva (2013)

Living reality (2012)

Moja psychológia

(2013)

Oborník, P. (2013)

Orgoňová, O., Maliková, V. (2005)

Slovenské letáky

(2012-2019)

Slovenská televízia

(2015)

Youtube (2013 - 2018) creation of occasionalisms in the modern English language advertising texts // Filolohichni nauky, kn. 1, s. 63 - 66).

Особливості творення неологізмів-телескопізмів у сучасній англійській мові (на матеріалі лексикографічних джерел) // Науковий вісник Дрогобииького державного педагогічного університету імені Івана Франка. Сер: Філологічні науки (мовознавство). №3, с. 137 - 140. (Maliarchuk, O. V. Peculiarities of creation of neologisms-telescopisms in modern English (on material of lexicographic sources) // Naukovyi visnyk Drohobytskoho derzhavnoho pedahohichnoho universytetu imeni Ivana Franka. Ser. Filolohichni nauky (movoznavstvo). №3, s. 137 - 140.

Оказіоналізми як окрема група неологізмів // Вісник Житомирського держсавного університету. Філологічні науки, вип. 58, с. 52 - 55. (Romanchuk, $S$. Ye. Occasionalisms as a separate group of neologisms // Visnyk Zhytomyrskoho derzhavnoho universytetu. Filolohichni nauky, vyp. 58, s. $52-55$.)

За някои особености на езика на рекламните текстове // LiterNet, 23.03.2008, № 3 (100), <http://liternet.bg/publish22/d_todorova/reklamni.htm>. (Todorova, D. On some peculiarities of the advertising texts language // LiterNet, 23.03.2008, № 3 (100), <http://liternet.bg/publish22/d_todorova/reklamni.htm >)

Оказіоналізми у мові української преси 90-х років XX ст. Автореф. дис. .. канд. філол. наук, спец. 10.02.01 “Українська мова". Дніпропетровськ, 2005. 19 c. (Turchak, O. M. Occasionalisms in the language of the Ukrainian press in the 90s of the XX c. Avtoref. dys. ... kand. filol. nauk, spec. 10.02.01 "Ukraiinska mova". Dnipropetrovsk, 2005. 19 s.)

Українські рекламні листівки. 2012; 2013; 2014; 2016; 2017; 2018; 2019. (Ukrainian promotional cards. 2012; 2013; 2014; 2016; 2017; 2018; 2019.)

Українське телебачення. 2014; 2015; 2017; 2018; 2019. (Ukrainian television. $2014 ; 2015 ; 2017 ; 2018 ; 2019$.)

Сучасний український рекламний міф. Х.: Харківське історико-філологічне товариство. (Khavkina, L. Modern Ukrainian advertising myth. Kh.: Kharkivske istoryko-filolohichne tovarystvo.)

Eva. 2012, č. 1. $188 \mathrm{~s}$.

Eva. 2013, č. 1.188 s.

Living reality. 2012 , č. $9-10.28$ s.

Moja psychológia. 2013, Február. 132 s.

Ko(mo)difikácia jazyka // Jazyk a kultúra: internetový časopis, roč. 4, číslo 16/2013, Filozofická fakulta Prešovskej univerzity v Prešove. 02.10.2019. <file://C:/Users/User/Downloads/ obornik.pdf>

Jazykové variácie súčasného reklamného textu. Teória a sociolingvistický prieskum. Česká a slovenská slavistika na počátku 21. století. Brno: Masarykova univerzita, s. $171-188$.

Slovenské letáky. 2012; 2013; 2014; 2017; 2018; 2019.

Slovenská televízia. 2015.

www.youtube.com. 2013; 2015; 2016; 2018. 